University of South Carolina

Scholar Commons

3-21-2007

\title{
Submarine Volcanic Morphology of the Western Galapagos Based on EM300 Bathymetry and MR1 Side-Scan Sonar
}

Jennifer B. Glass

Arizona State University at the Tempe Campus

D J. Fornari

Hillary F. Hall

University of Washington - Seattle Campus

Allison A. Cougan

University of Washington - Seattle Campus

Heidi A. Berkenbosch

University of Washington - Seattle Campus

See next page for additional authors

Follow this and additional works at: https://scholarcommons.sc.edu/geol_facpub

Part of the Earth Sciences Commons

Publication Info

Published in Geochemistry, Geophysics, Geosystems, Volume 8, Issue 3, 2007, pages 1-16.

Glass, J. B., Fornari, D. J., Hall, H. F., Cougan, A. A., Berkenbosch, H. A., Holmes, M. L., White, S. M., De La Torre, G. (2007). Submarine volcanic morphology of the western Galapagos based on EM300 bathymetry and MR1 side-scan sonar. Geochemistry, Geophysics, Geosystems, 8 (3), 1-16.

(c) Geochemistry, Geophysics, Geosystems 2007, American Geophysical Union

This Article is brought to you by the Earth, Ocean and Environment, School of the at Scholar Commons. It has been accepted for inclusion in Faculty Publications by an authorized administrator of Scholar Commons. For more information, please contact digres@mailbox.sc.edu. 


\section{Author(s)}

Jennifer B. Glass, D J. Fornari, Hillary F. Hall, Allison A. Cougan, Heidi A. Berkenbosch, Mark L. Holmes, Scott M. White, and Giorgio De La Torre 


\title{
Submarine volcanic morphology of the western Galápagos based on EM300 bathymetry and MR1 side-scan sonar
}

\author{
Jennifer B. Glass \\ School of Oceanography, Department of Earth and Space Sciences, University of Washington, Seattle, Washington \\ 98195, USA \\ Geology and Geophysics Department, Woods Hole Oceanographic Institution, Woods Hole, Massachusetts 02543, USA \\ Now at School of Earth and Space Exploration, Arizona State University, Tempe, Arizona 85287, USA \\ (jennifer.b.glass@asu.edu)

\section{Daniel J. Fornari} \\ Geology and Geophysics Department, Woods Hole Oceanographic Institution, Woods Hole, Massachusetts 02543, USA
}

\section{Hillary F. Hall}

School of Oceanography, Department of Earth and Space Sciences, University of Washington, Seattle, Washington 98195, USA

Allison A. Cougan, Heidi A. Berkenbosch, and Mark L. Holmes
School of Oceanography, University of Washington, Seattle, Washington 98195, USA

Scott M. White

Department of Geological Sciences, University of South Carolina, Columbia, South Carolina 29208, USA

\section{Giorgio De La Torre}

Instituto Oceanografico de la Armada (INOCAR), Guayaquil, Ecuador

[1] A compilation of high-resolution EM300 multibeam bathymetric and existing MR1 side-scan sonar data was used to investigate the volcanic morphology of the flanks of the western Galápagos Islands. The data portray an assortment of constructional volcanic features on the shallow to deep submarine flanks of Fernandina, Isabela, and Santiago Islands, including rift zones and groups of cones that are considered to be the primary elements in constructing the archipelagic apron. Ten submarine rift zones were mapped, ranging in length from 5 to $20 \mathrm{~km}$, comparable in length to western Canary Island rift zones but significantly shorter than Hawaiian submarine rift zones. A detailed analysis of the northwestern Fernandina submarine rift, including calculated magnetization from a surface-towed magnetic study, suggests that the most recent volcanism has focused at the shallow end of the rift. Small submarine volcanic cones with various morphologies (e.g., pointed, cratered, and occasionally breached) are common in the submarine western Galápagos both on rift zones and on the island flanks where no rifts are present. At depths greater than $\sim 3000 \mathrm{~m}$, large lava flow fields in regions of low bathymetric relief have been previously identified as a common seafloor feature in the western Galápagos by Geist et al. (2006); however, their source(s) remained enigmatic. The new EM300 data show that a number of the deep lava flows originate from small cones along the mid-lower portion of the NW submarine rift of Fernandina, suggesting that the deep flows owe their origin, at least in part, to submarine rift zone volcanism. 
Components: 7672 words, 9 figures, 3 tables.

Keywords: Galápagos Islands; EM300 multibeam bathymetry; MR1 side-scan sonar; submarine volcanic cones; submarine volcanic rift zones; deep lava flows.

Index Terms: 3037 Marine Geology and Geophysics: Oceanic hotspots and intraplate volcanism; 8427 Volcanology: Subaqueous volcanism; 3005 Marine Geology and Geophysics: Marine magnetics and paleomagnetics (1550).

Received 28 August 2006; Revised 1 December 2006; Accepted 21 December 2006; Published 21 March 2007.

Glass, J. B., D. J. Fornari, H. F. Hall, A. A. Cougan, H. A. Berkenbosch, M. L. Holmes, S. M. White, and G. De La Torre (2007), Submarine volcanic morphology of the western Galápagos based on EM300 bathymetry and MR1 side-scan sonar, Geochem. Geophys. Geosyst., 8, Q03010, doi:10.1029/2006GC001464.

\section{Introduction}

[2] The morphology and structure of oceanic islands in hot spot archipelagos provide insights into how these oceanic islands grow and evolve. The volcanic islands of the Galápagos Archipelago erupted over the last $\sim 10 \mathrm{Myr}$ on the Nazca plate in the eastern equatorial Pacific Ocean (Figure 1a) [Wilson and Hey, 1995]. The youngest islands are located at the western edge of the archipelago due to eastward movement of the Nazca Plate relative to the Galápagos hot spot [Gripp and Gordon, 2002]. ${ }^{3} \mathrm{He} /{ }^{4} \mathrm{He}$ ratios suggest that the leading edge of hot spot volcanism in this area currently lies under the westernmost island of Fernandina [Graham et al., 1993; Kurz and Geist, 1999]. Despite the unique geological and biological characteristics of the Galápagos Islands [e.g., Darwin, 1860, 1896; Simkin, 1984] and their location near the first discovered mid-ocean ridge hydrothermal vents [e.g., Ballard et al., 1979; Corliss et al., 1979], the submarine geology of the islands has remained relatively unexplored until recently [Christie et al., 1992; Fornari et al., 2001; Kurz et al., 2001; Harpp et al., 2003; Diefenbach, 2005; Geist et al., 2006].

[3] Our study builds on investigations conducted on three previous research cruises around the Galápagos, including the 1990 PLUME-2 cruise that concentrated on eastern Galápagos seamounts [Christie et al., 1992; Sinton et al., 1996], the 2000 AHA-Nemo 2 cruise, and the 2001 DRIFT4 cruise [Fornari et al., 2001; Kurz et al., 2001; Harpp et al., 2003; Geist et al., 2005, 2006]. The latter cruises collected EM120 and SeaBeam multibeam bathymetry and MR1 side-scan sonar backscatter data around the western Galápagos (Figures $1 \mathrm{~b}$ and 1e). The EM300 multibeam bathymetry data used in this study were collected in 2006 on $\mathrm{R} / \mathrm{V}$
Thomas G. Thompson cruises 188 and 189 (TN188 and TN189) (Figure 1c).

[4] Previous multibeam mapping of the submarine flanks of Fernandina Island [Fornari et al., 2001; Harpp et al., 2003; Diefenbach, 2005; Geist et al., 2006] revealed the presence of three well-developed submarine rift zones extending southwest, west and northwest from the island's western flank. Other prominent features of the region west of Fernandina are submarine lava flows erupted on low gradient seafloor in deep (>3000 m) water, recognized as regions of high backscatter in MR1 side-scan sonar data [Geist et al., 2006] (Figure 1e).

[5] The present study focuses on the submarine geology of the three westernmost Galápagos Islands: Fernandina, Isabela (including the flanks of Ecuador and Wolf volcanoes) and Santiago Islands, as well as Canal Isabela and the flanks of Roca Redonda (Figure 1c). We present new EM300 bathymetry that has approximately four times the resolution of previous multibeam data (see visual resolution comparison in Figures $2 \mathrm{a}$ and $2 \mathrm{~b})$. The high-resolution EM300 (25 m grid) multibeam bathymetric data and MR1 (8 m grid) sidescan sonar backscatter data are supplemented by a surface-towed magnetic survey completed on TN189 over Fernandina's northwestern submarine rift zone. Co-registration of EM300 bathymetry with MR1 side-scan sonar imagery permits more detailed interpretation of submarine volcanic features in the western Galápagos and better understanding of the processes responsible for their formation.

\section{Data Collection}

[6] Multibeam bathymetry and amplitude (backscatter) data were collected using a Simrad Kongsberg $30 \mathrm{kHz}$ EM300 sonar system. The hull-mounted 


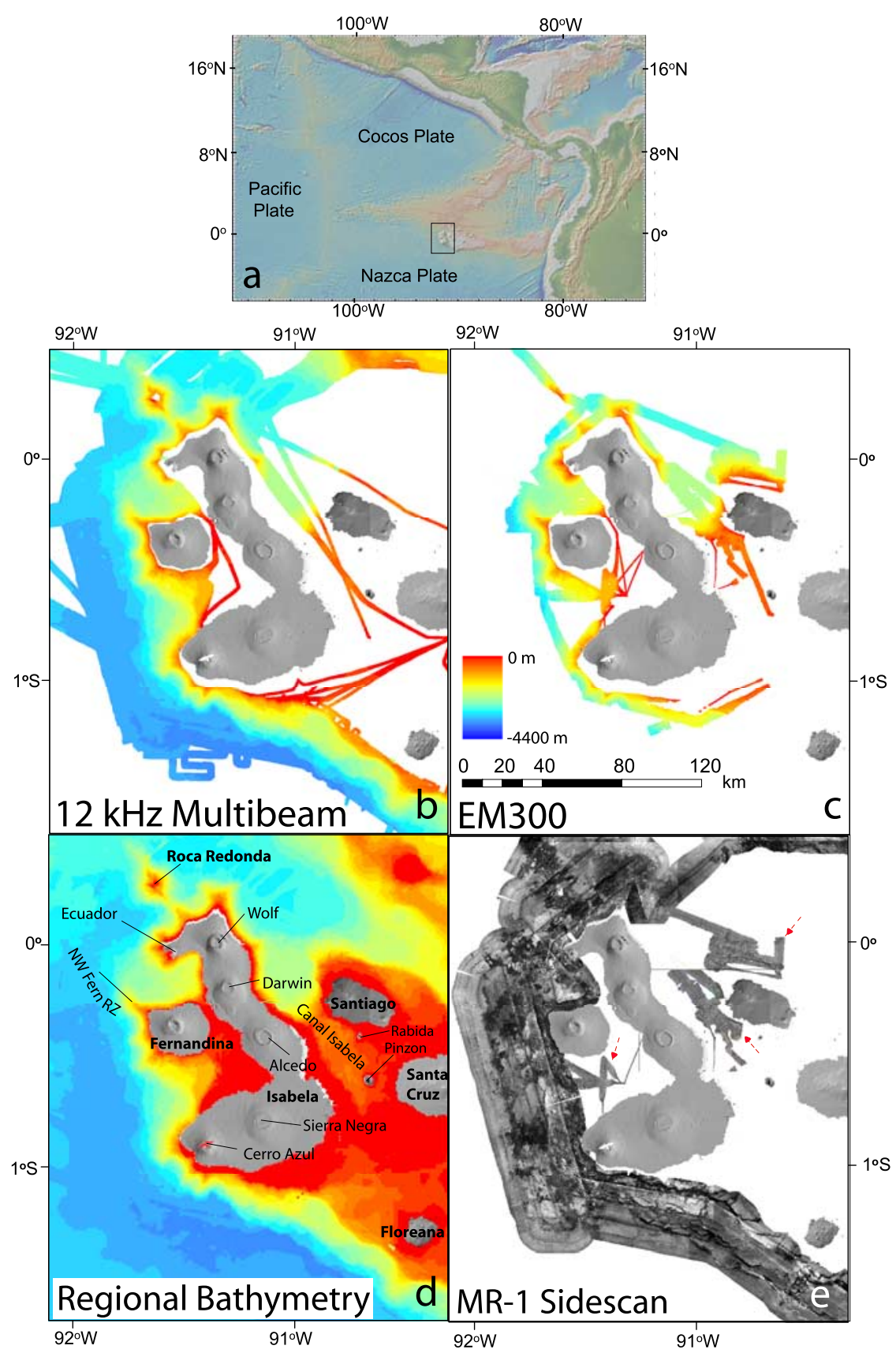

Figure 1. (a) Map of the eastern equatorial Pacific Ocean (GeoMapApp data) showing Pacific, Cocos, and Nazca Plates with box around western Galapagos study area, displayed in Figures $1 \mathrm{~b}-1 \mathrm{e}$. TOPSAR DEM data for Fernandina and Isabela Islands (40 m resolution) courtesy of D. Scheirer (Brown University) and Scott Rowland (University of Hawaii). DEM data (50 m resolution) for Santiago and other islands courtesy of M. Souris, Asian Institute of Technology (http://rslultra.star.ait.ac.th/ souris/ecuador.htm). Scale and water depth bars are all the same as shown in Figure 1c. (b) $12 \mathrm{kHz}$ multibeam bathymetry (100 m resolution) from PLUME-2, AHA-Nemo2, and DRIFT4 cruises. (c) EM300 (25 m resolution) multibeam bathymetry from TN188 and TN189 cruises. (d) Compiled bathymetric data (1 km resolution) courtesy of W. Chadwick, Oregon State University (http://www.pmel.noaa.gov/ vents/staff/chadwick/galapagos.html), AHA-Nemo2, DRIFT4, TN188, and TN189 cruises, showing five westernmost Galapagos Islands (Fernandina, Isabela, Santiago, Santa Cruz, and Floreana), the six volcanoes of Isabela Island (Ecuador, Wolf, Darwin, Alcedo, Sierra Negra, and Cerro Azul), small islands (Roca Redonda, Rabida, and Pinzon), the NW Fernandina rift, and the shallow waterway between Isabela and Santiago Islands (Canal Isabela). (e) Backscatter data from MR1 side-scan sonar from DRIFT4 cruise (gridded at $8 \mathrm{~m}$ resolution) and EM300 backscatter from TN188 and TN189 (gridded at $25 \mathrm{~m}$ resolution) marked with red arrows. Side-scan images have been inverted so that dark represents high backscatter and light is low backscatter or acoustic shadow. 


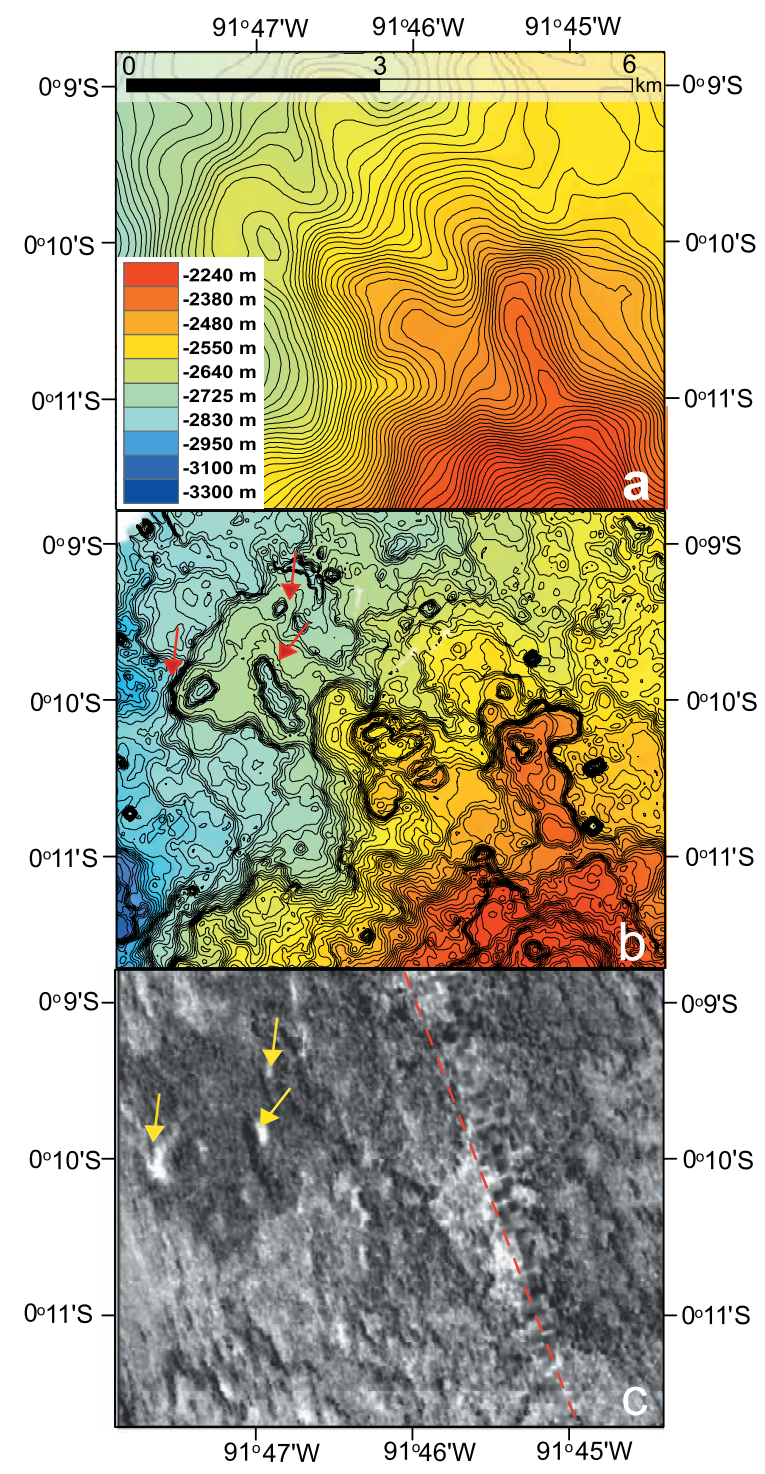

Figure 2. Comparison of (a) $12 \mathrm{kHz}$ multibeam bathymetry data (gridded at $100 \mathrm{~m}$ resolution) to (b) EM300 multibeam bathymetry data (gridded at $25 \mathrm{~m}$ resolution) and (c) MR1 side-scan sonar data (gridded at $8 \mathrm{~m}$ resolution), for the distal tip of the NW Fernandina rift. Bathymetric contour intervals are $10 \mathrm{~m}$; scale and water depth bars are shown in Figure 2a. Arrows point to correlating features in EM300 bathymetry (red) and MR1 side-scan sonar (yellow) for navigational co-registration check. Red dashed line indicates nadir in MR1 side-scan sonar data. Arrows also indicate the origin of a deep lava flow (higher backscatter in Figure 2c) from a group of perched lava pond vents. Location given in Figure 5.
EM300 transducer array transmits 135 beams per ping with vertical and horizontal resolution approximately 0.2 and $2 \%$ of water depth, respectively. Ship navigation was by P-Code GPS; motionsensing/attitude corrections were made with a POS/MV Model 320 vertical reference unit. AHA-Nemo2 and DRIFT4 multibeam bathymetric and side-scan sonar data collection methods are described by Geist et al. [2006]. EM300 bathymetric data were cleaned, merged, corrected for grazingangle and gridded at $25 \mathrm{~m}$ spacing. EM300 bathymetric and MR1 side-scan sonar data were checked visually for navigational co-registration, which is excellent (Figures $2 b$ and $2 c$ ).

\section{Data Analysis}

[7] Geist et al. [2006] identified five geomorphic provinces in the western Galápagos: submarine rift zones, large deep-water lava fields, shallow steepsloped submarine flanks, mass-wasting and erosional deposits, and submarine terraces. We add to this list small-scale volcanic structures, namely volcanic cones of various morphologies, mapped with the EM300 system. EM300 bathymetry and MR1 side-scan sonar data presented for the submarine flanks of Isabela Island (Ecuador and Wolf volcanoes) reveal the prevalence of submarine rift zones as well as scattered deep lava flows. Limited EM300 coverage for the erosional volcanic remnant of Roca Redonda, north of Isabela Island, supplemented with previously collected bathymetric data, suggest that Roca Redonda possesses six resistant volcanic ribs that may have been sites of focused magma supply during its construction. EM300 bathymetry data show that the north flank of Santiago Island lacks focused submarine rift zones, and is instead densely populated with volcanic cones at water depths of 700-2000 m (Figure 3b). Rift zones are, however, found in many other submarine regions of the eastern Galápagos, including Santiago (extending offshore from the eastern half of the island), Santa Cruz and San Cristobal (D. J. Geist, personal communication, 2006).

\subsection{Submarine Rift Zones}

[8] In our data analysis, we use the term "rift zone" when referring to linear or gently curving ridges greater than several kilometers in length, extending sub-perpendicularly away from volcanic islands and characterized by mottled backscatter [e.g., Lonsdale, 1989; Smith et al., 2002]. The submarine flanks of Fernandina Island are characterized by well-defined rift zones extending south- 


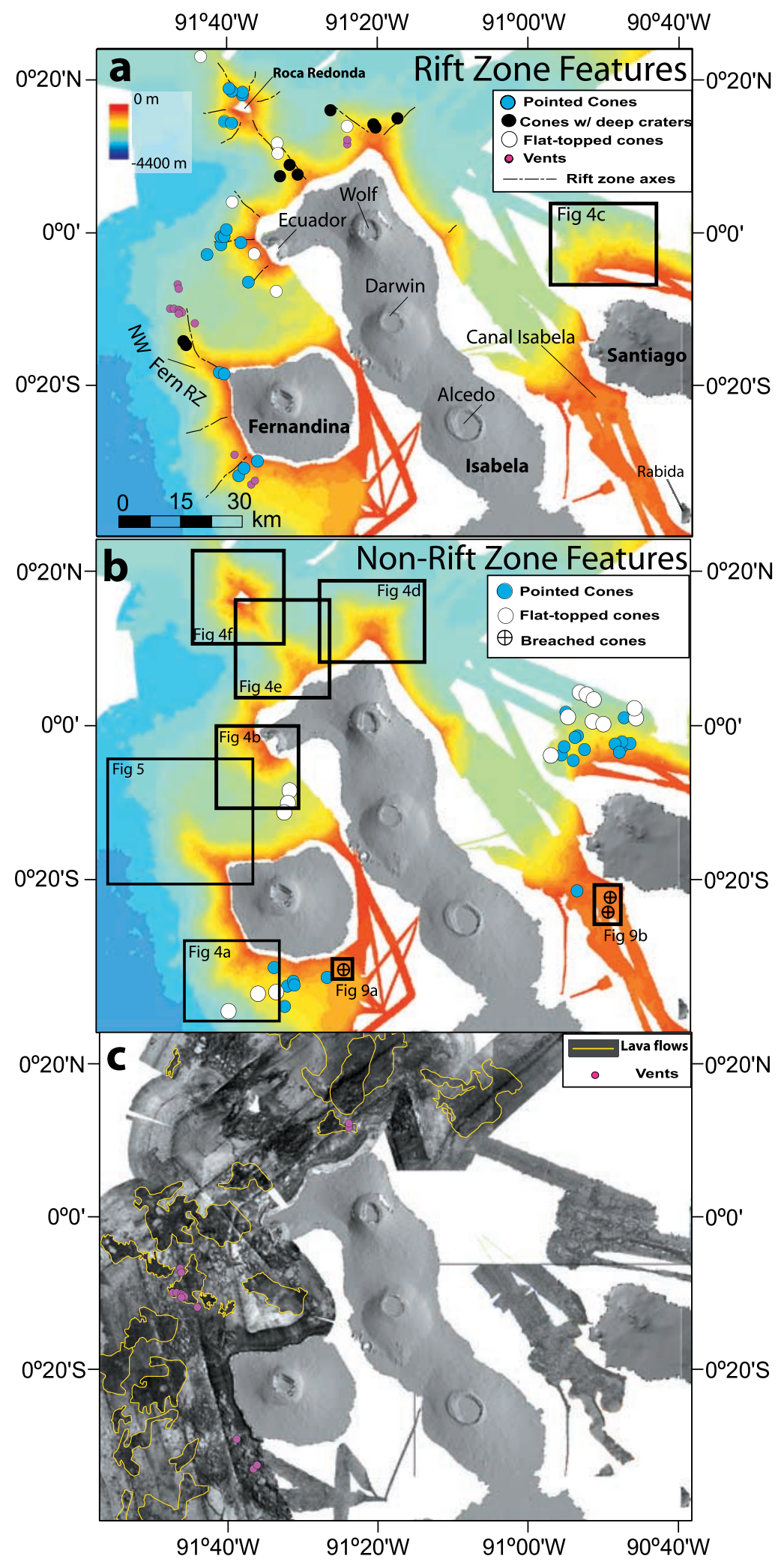

Figure 3. Distribution of submarine volcanic cone and vent morphologies on (a) rift zones and (b) non-rift-zone areas in the study region (western Galapagos Archipelago; see Figure 1). Data sources as in Figure 1. Scale and water depth bars are the same for both Figure 3a and Figure 3b. (c) Distribution of deep lava flow fields (yellow) from MR1 side-scan sonar data, with vents shown in pink as in Figure 3a. Locations of Figures 4a-4f (excluding Figure 4c, given in Figure 3a), 5, and 9a-9b are given in Figure $3 \mathrm{~b}$. 
Table 1. Lengths and Trends of Study Area Submarine Rift Zones and Resistant Ribs of Roca Redonda

\begin{tabular}{lcl}
\hline \multicolumn{1}{c}{ Rift Zone Name } & Length, km & Strike, deg \\
\hline SW Fernandina & 15 & 225 \\
W Fernandina & 12 & 250 \\
NW Fernandina & 20 & 300 (proximal); \\
& & 350 (distal) \\
NW Ecuador & 9 & 320 \\
W Ecuador & 10 & 275 \\
SW Ecuador & 8 & 220 \\
NW Wolf & 10 & 320 \\
NW Roca Redonda & 10.5 & 330 \\
NE Roca Redonda & 5 & 20 \\
E Roca Redonda & 6.5 & 70 \\
SE Roca Redonda & 9.5 & 150 \\
SW Roca Redonda & 8 & 220 \\
W Roca Redonda & 6.5 & 265 \\
N Wolf (NW) & 11.5 & 310 \\
N Wolf (NE) & 10.5 & 50 \\
Wolf-Darwin & $\sim 10$ & 60 \\
\hline
\end{tabular}

west, west and northwest of the island, with lengths of 15, 12 and $20 \mathrm{~km}$ [Harpp et al., 2003; Geist et al., 2006] (Figure 3a and Table 1). Ecuador Volcano also possesses three rift zones extending southwest, west and northwest with lengths of 8,10 and $9 \mathrm{~km}$ [Harpp et al., 2003; Geist et al., 2006]. One rift zone $(10 \mathrm{~km}$ long) extends northwest from Wolf Volcano toward Roca Redonda and is the submarine continuation of the "NW diffuse rift" described by Geist et al. [2005]. Roca Redonda has a "star"-shaped morphology comprising six radial ridges ranging in length from 5 to $10.5 \mathrm{~km}$, forming three lineaments trending $\mathrm{NE}-\mathrm{SW}, \mathrm{W}-\mathrm{E}$ and NW-SE (Figure 4f). Wolf Volcano has two rift zones at its northern tip extending NW and NE with lengths of 10.5 and $11.5 \mathrm{~km}$, respectively [Geist et al., 2005, 2006] (Figure 4d). Examination of EM300 bathymetry revealed another NE trending rift zone ( $\sim 10 \mathrm{~km}$ in length) between Wolf Volcano and Darwin Volcano (Figure 3a).
[9] We identified four rift zone-associated volcanic morphologies using EM300 bathymetric data: (1) pointed cones, (2) cones with deep craters, (3) flat-topped cones, and (4) vents (Figure 3a). Rift zone pointed cones are characterized by steep $\left(30^{\circ}\right)$ slopes and predominantly elongate morphologies, and are present on the SW and NW rifts of Fernandina and Ecuador Volcano, as well as the northern Roca Redonda (Figures 3a, 4a, 4b, and 4f). Rift-zone cones with deep craters (50-100 m deep) have cone diameters ranging from 500 to $\sim 2000 \mathrm{~m}$ (Figures $3 \mathrm{a}$ and $4 \mathrm{e}$ ).

[10] Flat-topped cones differ from terraces in that at least two-thirds of their sides are elevated above the surrounding seafloor, whereas individual flattopped cones may accumulate to form terraces [e.g., Diefenbach, 2005]. Flat-topped cones with heights of 100 to $180 \mathrm{~m}$ and diameters of 1.4 to $2.5 \mathrm{~km}$ (aspect ratios 0.04-0.09), commonly containing central domes or depressions, are present on the rift zones of northern Isabela and northern part of Roca Redonda, as well as the flanks of Fernandina and rifts of Ecuador Volcano (Figures 3a, 4a, and 4b).

\subsubsection{Northwestern Fernandina Submarine Rift Zone}

\subsubsection{EM300 Bathymetric and MR1 Side-Scan Sonar Analysis}

[11] The NW Fernandina rift zone has previously been described by Fornari et al. [2001], Harpp et al. [2003, Table 1], and Geist et al. [2006]. It is $20 \mathrm{~km}$ long, has an average gradient of $160 \mathrm{~m} / \mathrm{km}$ and bends from a strike of $300^{\circ}$ to $350^{\circ}$ at $\sim 1700 \mathrm{~m}$ water depth (Figures 5a and 5c and Table 1). The rift zone is characterized by mottled backscatter in MR1 side-scan sonar records (Figure 5b) [Geist et al., 2006]. When co-registered with EM300 bathymetry, a $53 \mathrm{~km}^{2}$ region of high backscatter

\footnotetext{
Figure 4. Examples of rift zone and non-rift-zone features from EM300 bathymetry for locations shown in Figures $3 \mathrm{a}$ and $3 \mathrm{~b}$. Contour intervals are $25 \mathrm{~m}$. Color bar is the same for all and is shown in Figure 4c. Rift zones are delineated with white dashed lines, cones are marked with cyan dashed circles, flat-topped cones are marked with magenta dashed circles, and deep craters are marked with green dashed circles. (a) Cones (symmetrical and elongate) on the southwestern rift zone of Fernandina Island and flat-topped cones on terraces. (b) Western and southwestern Ecuador Volcano rift zones and associated rift-zone flat-topped cones and elongate cones. Three non-rift-zone cones are located south of Ecuador Volcano's rift zones. Purple dashed line outlines debris lobe from the Ecuador Volcano sector collapse [Rowland et al., 1994; Geist et al., 2002; Mitchell, 2003] that removed the western half of the volcano. (c) North flank of Santiago Island. Magenta dashed line marks the boundary between dominantly cone morphologies (south) and dominantly flat-topped cone morphologies (north). (d) Rift zones of northern Wolf Volcano, with flattopped rift-zone cone outlined in magenta. (e) Ecuador-Wolf rift zone and southeastern Roca Redonda rift zone with deep craters outlined with green and flat-topped rift-zone cones marked with magenta. (f) Six resistant ribs of Roca Redonda (RR).
} 

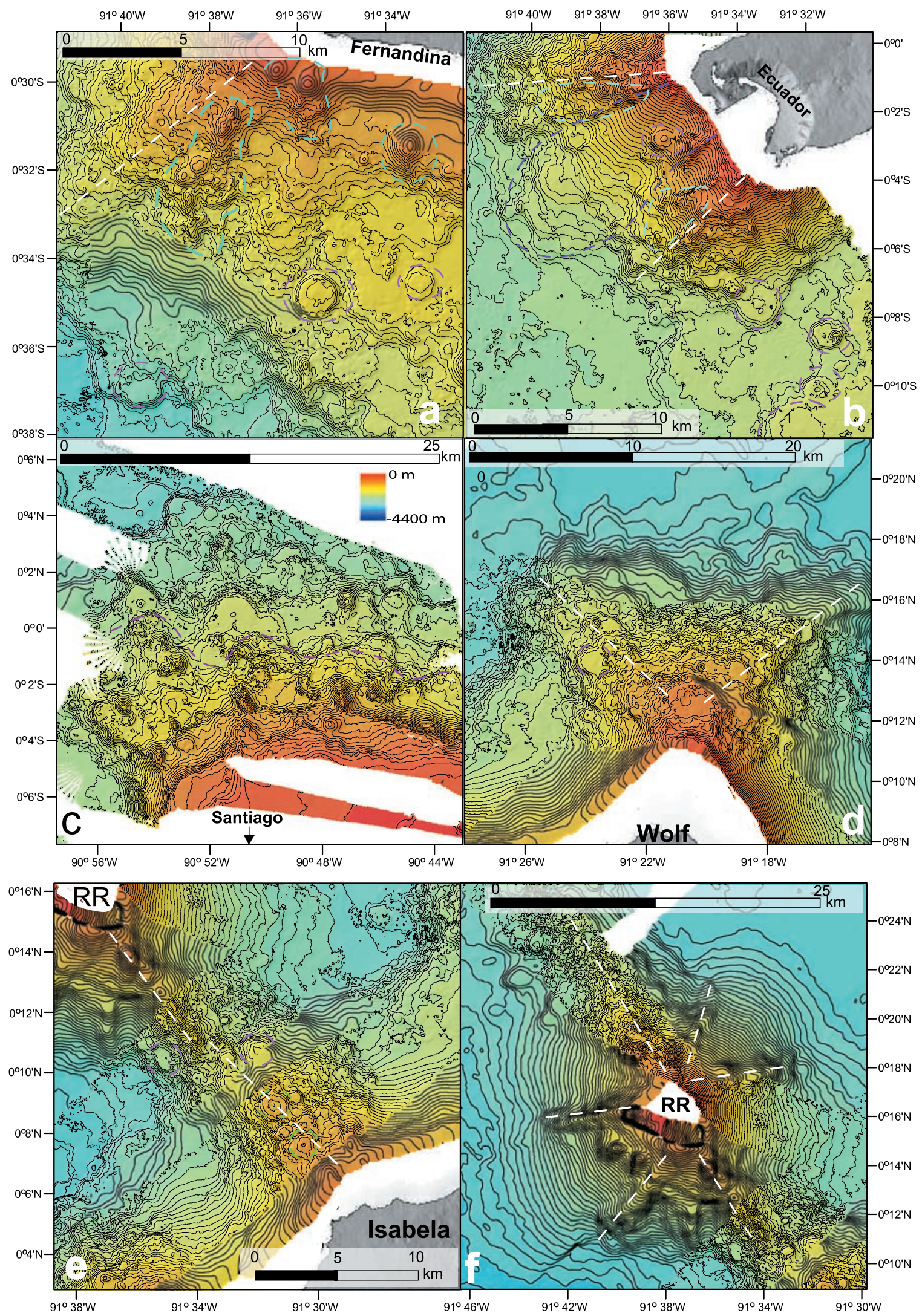

Figure 4 


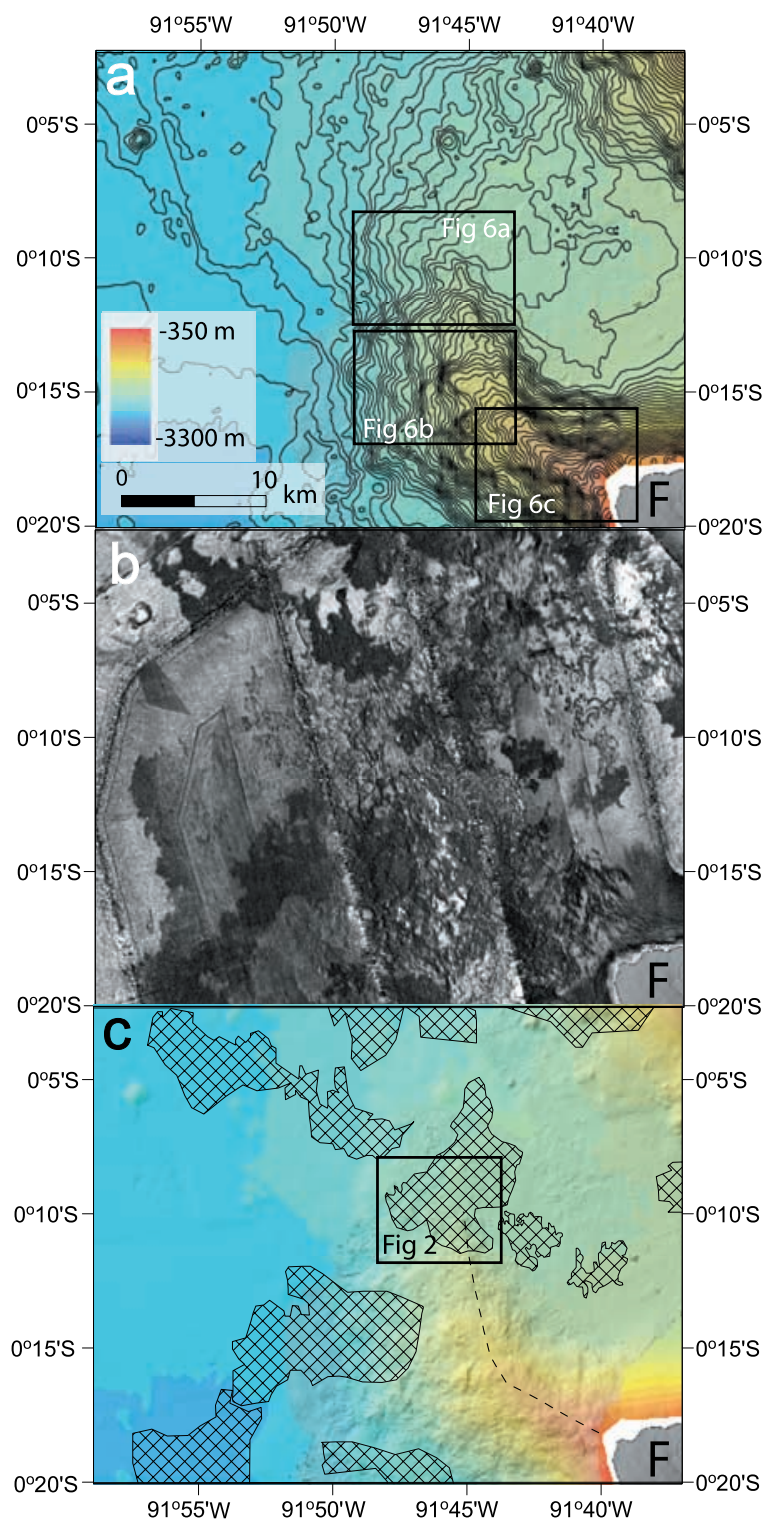

Figure 5. (a) Bathymetric (50 $\mathrm{m}$ contours) and (b) backscatter data for the NW Fernandina rift. Scale bar is the same for all and is shown in Figure 5a. Bathymetric data are compiled from DRIFT4, TN188, and TN189; backscatter data are MR1 side-scan sonar data collected on DRIFT4. (c) Compiled interpretation showing hashed outlines of deep lava flows and axis (black) of NW Fernandina rift. "F" stands for Fernandina Island. Location of Figure 6 is given in Figure 5a, and location of Figure 2 is given in Figure $5 \mathrm{c}$.

at the distal tip of the rift, previously described by Geist et al. [2006], is found to originate from elongate vents that have perched lava pond morphologies [e.g., Clague et al., 2000] (Figures 2b, $6 \mathrm{a}$, and $\left.6 \mathrm{a}^{\prime}\right)$. In the middle region of the rift between $\sim 1500 \mathrm{~m}$ and $2500 \mathrm{~m}$ depths, two 800-mdiameter cones with deep craters (Figure $6 \mathrm{~b}$ ) sur- rounded by high backscatter mottled reflectivity (Figure $6 \mathrm{~b}^{\prime}$ ) are present. A ridge $2.5 \mathrm{~km}$ long with $25-30^{\circ}$ slopes is on the south flank of the NW Fernandina rift at $1680 \mathrm{~m}$ depth, with a valley splitting its western half in two (Figure 6b). The ridge is characterized by low backscatter, with higher backscatter along the spine and western valley (Figure 6b'). Semi-circular terraces, interpreted as flow lobes, extend down the southern flank of the NW rift (Figure 6b). Closer to Fernandina's coastline, a field of cones is apparent in bathymetric data (Figure 6c), but they are nearly distinguishable in backscatter data, with only slightly lower backscatter than mottled acoustic terrain to the northwest (Figure $6 \mathrm{c}^{\prime}$ ). The acoustically smooth character in MR1 data and relatively featureless slopes in bathymetric data on the middle-western flank of Fernandina indicates abundant fragmental material, resulting from debris slides and disintegration of subaerial lava flows entering the ocean and subsequently being transported down slope [Mitchell, 2003; Geist et al., 2006] (Figures 6c and $6 \mathrm{c}^{\prime}$ ).

[12] Cross-axial profiles made along the length of the NW rift reveal a symmetrical ridge axis close to Fernandina Island, transitioning into an irregular, asymmetrical ridge axis in the distal portions of the rift zone (Figures 7a and 8). The western flank of the rift averages $12^{\circ}$ in slope, while the eastern flank averages $15^{\circ}$ in slope.

\subsubsection{Magnetic Survey of Fernandina's NW Submarine Rift}

[13] A magnetic survey of Fernandina's NW rift (Figure 7a) revealed a magnetic low (minimum of $-2400 \mathrm{nT}$ ) coinciding with the topographic expression of the ridge (Figures $7 \mathrm{a}$ and $7 \mathrm{~b}$ ). At equatorial latitudes, proximity to the magnetic source results in magnetic lows over normally polarized rock due to the near-horizontal magnetic field. Forward magnetic modeling was conducted using an assumed magnetization of $30 \mathrm{~A} / \mathrm{m}$ and measured bathymetry. We used the Parker [1973] Fourier method in order to assign a best-fit value (selected for the closest range the observed amplitude of magnetic anomaly and lowest root-meansquare value) to the thickness of magnetic extrusive volcanics covering the NW rift. We varied the model thickness of the extrusive volcanic magnetic layer at $500 \mathrm{~m}$ intervals between 0.5 and $2 \mathrm{~km}$, and performed one run with a layer of variable thickness to emulate the ridge's variable height from the seafloor. A thickness of $1.5 \mathrm{~km}$ results in a magnetic field range that is closest to that observed 

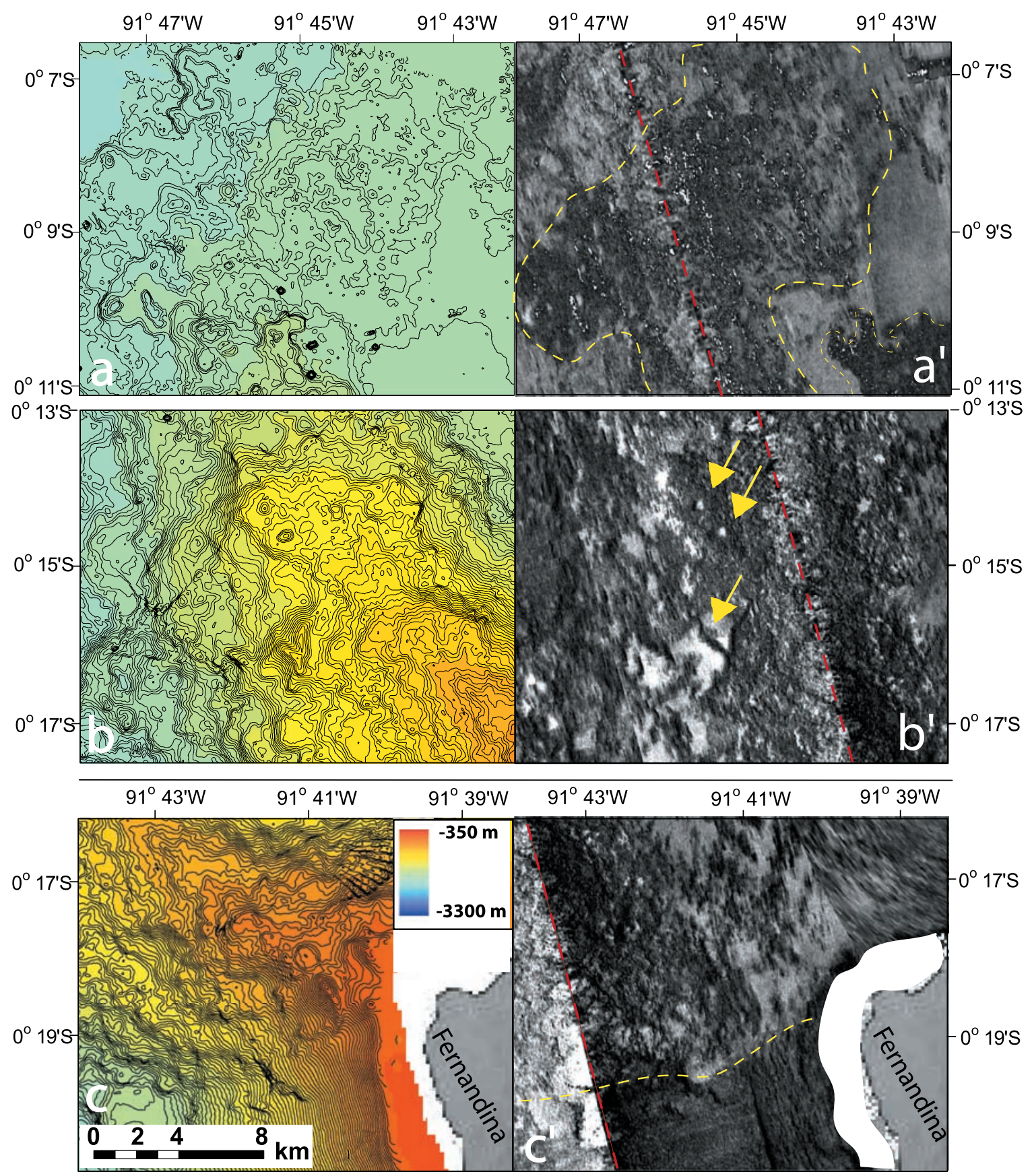

Figure 6. Bathymetric ( $25 \mathrm{~m}$ contours) and backscatter data for $\left(\mathrm{a}, \mathrm{a}^{\prime}\right)$ distal, $\left(\mathrm{b}, \mathrm{b}^{\prime}\right)$ middle, and (c, $\left.\mathrm{c}^{\prime}\right)$ proximal portions of the NW Fernandina rift. Bathymetric data are compiled from DRIFT4, TN188, and TN189; backscatter data are MR1 side-scan sonar data collected on DRIFT4. Scale and water depth color bar are the same for all and are shown in Figure 6c. Red dashed line indicates MR1 backscatter nadir. Yellow dashed line in Figure 6a' delimits a deep lava flow (high backscatter) at the distal tip of the NW Fernandina rift. Yellow arrows in Figure $6 \mathrm{~b}^{\prime}$ mark two cones with deep craters and ridge discussed in text. Yellow dashed line in Figure $6 \mathrm{c}^{\prime}$ marks boundary between mottled backscatter of the NW Fernandina rift (north) and smooth, high backscatter inferred to be mass wasting (south). Locations given in Figure 5a. 
while maintaining a low root-mean-square value (Table 2).

[14] Magnetic anomaly data were interpolated onto a grid with $500 \mathrm{~m}$ spacing and analyzed using a 3-D crustal inversion (based on the Parker and Huestis [1974] approach) with a $1.5 \mathrm{~km}$ thickness to calculate magnetization. An assumed direction of magnetization of $5^{\circ}$ declination and $19^{\circ}$ inclination was used for the latitude of the survey (between $0^{\circ} 10 \mathrm{~s}$ and $0^{\circ} 20 \mathrm{~s}$ ), and azimuthal filtering was employed to minimize instabilities. All calculated magnetization values were shifted in the positive direction by $10.25 \mathrm{~A} / \mathrm{m}$ to correct for negative calculated magnetization values, assuming that the entire NW Fernandina rift area has been completely paved over with recent normal polarity lavas since the Brunhes/Matuyama magnetic reversal $\sim 0.8 \mathrm{Ma}$. Calculated magnetization reveals a magnetic high

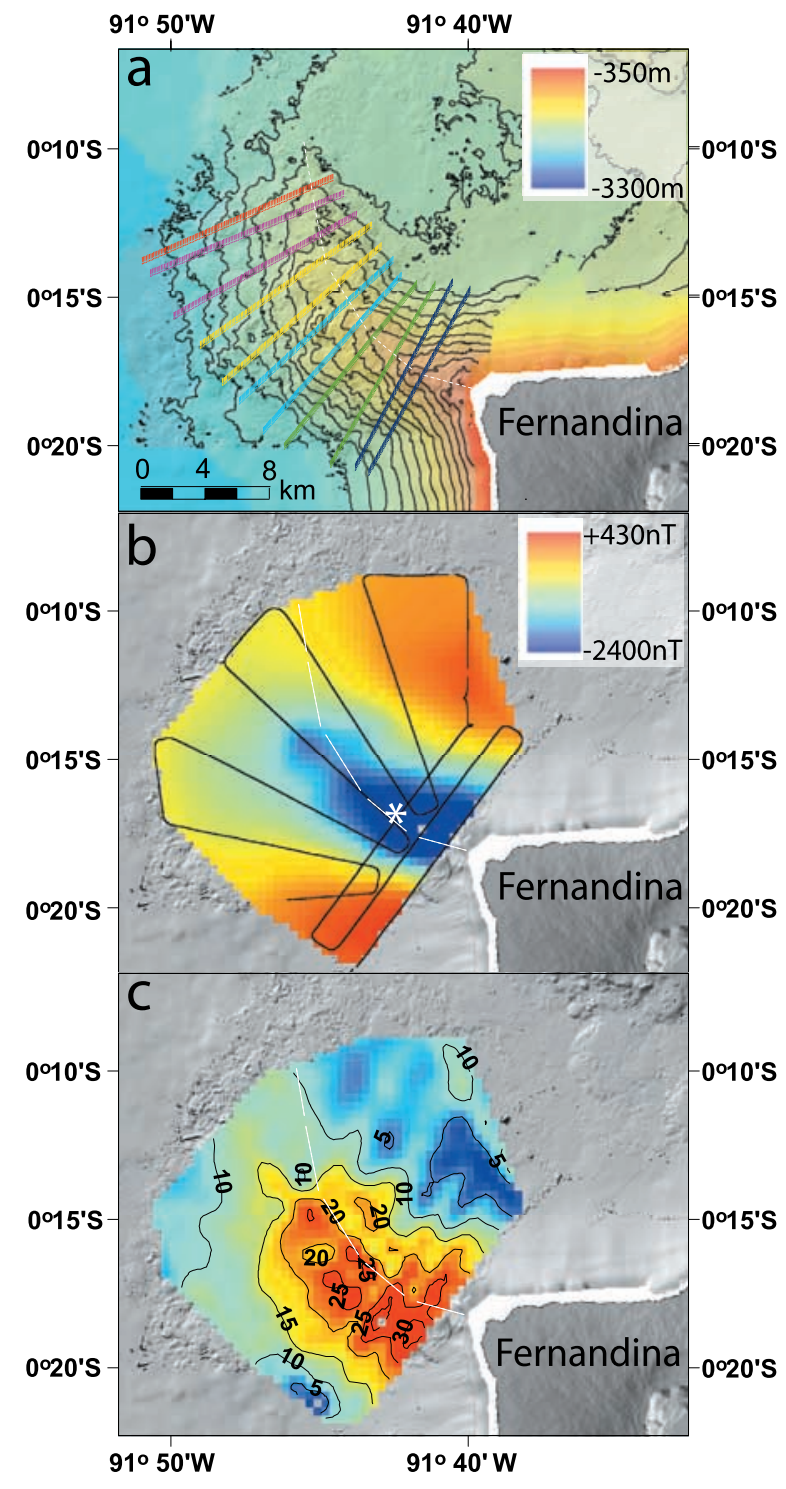

(up to $+32 \mathrm{~A} / \mathrm{m}$ ) concentrated on the southern flank of the middle to shallow portion of the NW rift (Figure 7c), suggesting that recent extrusive volcanism has been focused there, south of the bend at $\sim 1700$ m water depth.

[15] Measured magnetic values of sample D15 dredged on the DRIFT4 cruise at 1243-1142 m water depth on the NW rift [Geist et al., 2006] (Figure 7b) were found to be $3.43 \pm 0.99 \mathrm{~A} / \mathrm{m}$ (Table 3). While this low measured magnetization raises the question that the modeled thickness $(1.5 \mathrm{~km})$ may be too thin, we assume that the low magnetization is a result of extensive seafloor weathering of more magnetic basalt as evidenced by the visible $\mathrm{Fe}-\mathrm{Mn}$ crust on the exterior of sample D15.

\subsection{Areas Away From Submarine Rift Zones}

[16] Volcanic cones are also present on the submarine flanks of the islands in areas not associated

Figure 7. Bathymetric and magnetic survey results for the NW Fernandina rift. Data sources as in Figure 1. On cruise TN189, a Marine Magnetics ${ }^{\circledR}$ SeaSPY marine magnetometer with a sensitivity of $0.01 \mathrm{nT}$ and absolute accuracy of $0.2 \mathrm{nT}$ was towed at $50 \mathrm{~m}$ depth and sampled at a rate of $1 \mathrm{~Hz}$ during a survey of Fernandina's NW submarine rift zone. The position of the magnetometer behind the ship was determined by inserting an offset of $250 \mathrm{~m}$ into the GPS-derived vessel position, which in turn was corrected for distance between the ship's A-frame sheave and the GPSreceiving antenna. Magnetic field data collected on TN189 were reduced to anomaly by removing the International Geomagnetic Reference Field (IGRF) for 2005. In Figure 7, bathymetric (100 m contours) data were compiled from DRIFT4, TN188, and TN189 multibeam surveys. Profile lines (various colors) of Figure 8 are shown in Figure 7a. Scale bar is the same for all panels and is shown in Figure 7a. Measured magnetic field (Figure 7b) corrected to anomaly for 2005 IGRF with survey track lines. White asterisk indicates approximate location of dredge sample D15 on DRIFT4 cruise (see Table 1 for sample D15 magnetization measurements). (c) Three-dimensional calculated magnetization over the NW Fernandina Rift Zone (based on the Parker and Huestis [1974] inversion approach with azimuthal filtering and a magnetic source thickness layer value of $1.5 \mathrm{~km}$ ). Units are amps per meter. All calculated magnetization values were shifted in the positive direction by $10 \mathrm{~A} / \mathrm{m}$ to correct for negative calculated magnetization values. The highest calculated magnetization (up to $+32 \mathrm{~A} / \mathrm{m}$ ) values are found on the shallow, nearshore portion and southern flank of the NW Fernandina rift. 


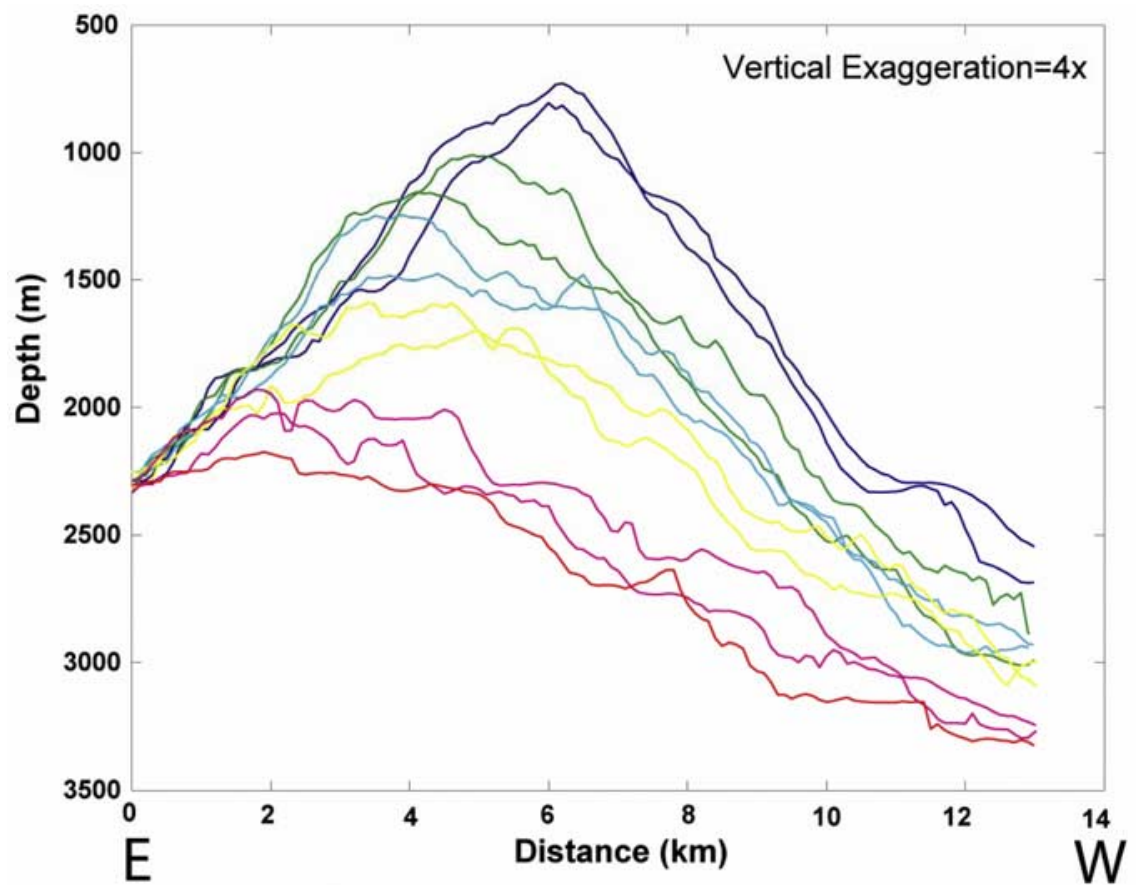

Figure 8. Cross-axial profiles of the NW Fernandina rift at $4 \times$ vertical exaggeration. All profiles start at the $1300 \mathrm{~m}$ contour on the east side and continue for a length of $13 \mathrm{~km}$ across-axis (profile lines shown in Figure 7a). Distal profiles (at greater water depth) are shown to be less symmetrical than proximal (shallower) profiles, suggestive of the formation of a well-developed dike complex underlying only the proximal regions of the rift zone.

with submarine rift zones. The greatest concentration of these features is on the southern flank of Fernandina and the northern flank of Santiago, regions that lack rift zones (Figure $3 b$ ). We identified three non-rift-zone-associated volcanic morphologies in EM300 bathymetric data: (1) pointed cones, (2) flat-topped cones, and (3) breached cones (Figure $3 b$ ). Non-rift-zone-associated cones are characterized, like rift zone cones, by steep slopes and pointed tops, and either conical or elongate morphologies. Cones have diameters of
$1-3 \mathrm{~km}$ and heights of $100-400 \mathrm{~m}$. A symmetrical pointed cone, $400 \mathrm{~m}$ in height with a $3 \mathrm{~km}$ basal diameter and $15^{\circ}$ slopes occupies the northern end of the Canal Isabela (Figure 3b). The cones on the southern flank of Fernandina and the northern flank of Santiago are commonly elongate and slightly curved. They are also generally located at water depths $<1500 \mathrm{~m}$, whereas flat-topped cones are generally located at water depths $>1500 \mathrm{~m}$. Flat-topped cones $140-200 \mathrm{~m}$ high and $1.6-3.5 \mathrm{~km}$ in diameter (aspect ratios 0.04-0.13), commonly

Table 2. Results of Forward Magnetic Models Over the NW Fernandina Submarine Rift Zone With an Assumed Magnetization Value of $30 \mathrm{~A} / \mathrm{m}$ and Measured Bathymetry Using the Parker [1973] Fourier Method ${ }^{\mathrm{a}}$

\begin{tabular}{lccc}
$\begin{array}{c}\text { Magnetic } \\
\begin{array}{c}\text { Source Thickness, } \\
\text { km }\end{array}\end{array}$ & $\begin{array}{c}\text { Maximum and } \\
\text { Root-Mean-Square } \\
\text { Value }\end{array}$ & $\begin{array}{c}\text { Minimum Magnetic } \\
\text { Field, nT }\end{array}$ & $\begin{array}{c}\text { Magnetic Field } \\
\text { Range, nT }\end{array}$ \\
\hline Measured & NA & +432 to -2410 & 2842 \\
Variable & 329 & +1206 to -4537 & 5743 \\
0.5 & 381 & +377 to -1044 & 1421 \\
1 & 319 & +944 to -1717 & 2661 \\
1.5 & $\mathbf{2 8 7}$ & $+\mathbf{1 0 5 5}$ to $-\mathbf{2 2 1 9}$ & $\mathbf{3 2 7 4}$ \\
2 & 275 & +1111 to -2593 & 3704 \\
\hline
\end{tabular}

\footnotetext{
${ }^{\mathrm{a}}$ Thickness of the extrusive volcanic magnetic layer was varied between 0.5 and $2 \mathrm{~km}$, at $500 \mathrm{~m}$ intervals, and one run was performed with a layer of variable thickness using the ridge's variable height from the seafloor for a thickness value. A thickness of $1.5 \mathrm{~km}$ (bold row) results in a magnetic field range that is closest to the observed range, while maintaining a low root-mean-square value.
} 
Table 3. Magnetic Intensity Measurements of DRIFT4 Sample D15, Dredged From the NW Fernandina Submarine Rift Zone at Water Depths Between 1243 and $1142 \mathrm{~m}^{\mathrm{a}}$

\begin{tabular}{cc}
\hline Dredge Name-Number & $\begin{array}{c}\text { Magnetic Intensity, } \\
\mathrm{A} / \mathrm{m}\end{array}$ \\
\hline D15-1a & 4.82 \\
D15-1b & 2.95 \\
D15-2a & 2.50 \\
D15-2b & 4.55 \\
D15-3a & 3.45 \\
D15-3b & 2.03 \\
D15-4a & 4.11 \\
D15-4b & 2.27 \\
D15-5a & 4.28 \\
D15-5b & 3.32 \\
Mean (D15) & $3.43 \pm 0.99$ \\
\hline
\end{tabular}

\footnotetext{
${ }^{\mathrm{a}}$ Sample dredge location shown in Figure 7 with white asterisk.
} Units are amps per meter $(\mathrm{A} / \mathrm{m})$.

containing central domes or depressions, are also present on the southern flank of Fernandina, on terraces north of Fernandina and on the northern flank of Santiago, where they form semicircular staircase terraces extending to the north (Figure 3b). Three breached cones with outer slopes of $15-20^{\circ}$ have been identified: one missing its western side, on the southeastern flank of Fernandina (Figure 9a), and two are missing their southwestern sides in Canal Isabela (Figure 9b).

\subsection{Deep Lava Flow Fields}

[17] Large deep-water lava fields have previously been described by Fornari et al. [2001] and Geist et al. [2006] and are found west and northwest of Fernandina, and west of Ecuador Volcano. Along with the flow fields mapped by Geist et al. [2006], we identify several additional small flow fields in the northern study area on the basis of well-defined regions of high backscatter. These include several large $\left(80-290 \mathrm{~km}^{2}\right)$ flow fields north of the Wolf rift zones, one $\left(26 \mathrm{~km}^{2}\right)$ flow field west of the Wolf rift zones and one small $\left(9 \mathrm{~km}^{2}\right)$ flow field west of Roca Redonda (Figure 3c).

[18] The majority of these flows are $>10 \mathrm{~km}$ long and are located in water depths $>3000 \mathrm{~m}$ in regions of low relief $\left(<5^{\circ}\right)$. Four deep flows extending northwestward from the NW Fernandina rift, a region with bathymetric relief $<3^{\circ}$, form a nearly continuous band trending $300^{\circ}$ (Figures $5 \mathrm{~b}$ and $5 \mathrm{c}$ ). Flows north of Fernandina's NW rift and west of the northern Wolf rift zones are associated with small volcanic constructional features imaged in the
EM300 data that may represent primary eruptive vents from which the flows originated (Figure 3c).

\section{Discussion}

\subsection{Submarine Rift Zones}

[19] The diffuse nature of Galápagos subaerial rift zones has been shown to differ from the welldeveloped nature of western Galápagos submarine rifts, likely due to greater deviatoric stresses in the submarine environment [Geist et al., 2006]. The northwestern and southwestern submarine rift zones of Fernandina are aligned with diffuse subaerial rift zones that have high concentrations of radial vents [Chadwick and Howard, 1991; Chadwick and Dieterich, 1995; Rowland, 1996], whereas there is no subaerial rift zone complement to the western Fernandina submarine rift zone [Geist et al., 2006]. There is also no subaerial rift zone complement to
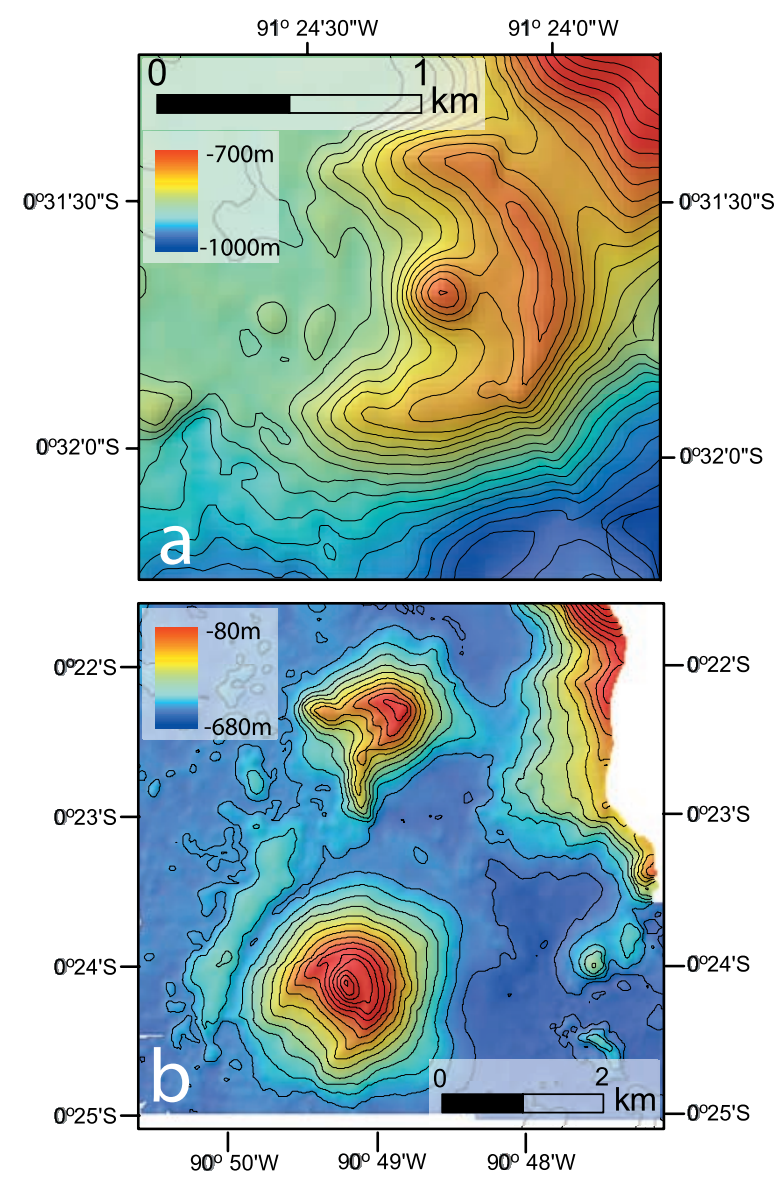

Figure 9. Breached cone EM300 bathymetric data for (a) southern Fernandina and (b) Canal Isabela. See Figure $3 \mathrm{~b}$ for location reference. Contours are (a) $10 \mathrm{~m}$ and (b) $25 \mathrm{~m}$. 
the northwestern Ecuador rift zone, although there are many young subaerial vents in the northwest Ecuador sector region [Rowland et al., 1994; Geist et al., 2002; Mitchell, 2003]. The western and southwestern rift zones of Ecuador Volcano extend into the submarine region from northern and southern segments of its dissected caldera, with the western submarine rift zone being semi-parallel to the subaerial "Northeast" Rift Zone [Rowland et al., 1994] or "East" Rift Zone [Geist et al., 2002]. The northwestern and northern submarine rift zones of Wolf Volcano extend from the "NW Diffuse Rift" and "N Diffuse Rift" zones described by Geist et al. [2005]. There is no subaerial continuation of the rift zone extending northeast between Wolf Volcano and Darwin Volcano [Chadwick and Howard, 1991] (Figure 3a).

[20] In contrast to other western Galápagos volcanoes in this study, Roca Redonda is an unbuttressed volcanic edifice [Standish et al., 1998]. Roca Redonda possesses six resistant ribs that form a stellate architecture [e.g., Mitchell, 2001] similar to that observed on the Geisha guyots, northwestern Pacific [Vogt and Smoot, 1984]. Abundant constructional volcanic morphologies identified in EM300 bathymetric data suggest that the NW-SE rift zone, semi-parallel to the active WNW-ESE extensional zone identified by Cando et al. [2006], may be the most recently active Roca Redonda rift zone.

[21] Western Galápagos rift zones range from 5 to $20 \mathrm{~km}$ in length, significantly shorter than the $30-$ $70 \mathrm{~km}$ submarine rift zones on the island of Hawai'i, but comparable to the $15-30 \mathrm{~km}$ long submarine rift zones seen on El Hierro and La Palma (Canary Islands) [Acosta et al., 2003]. Short Canary rift zones have been attributed to lower magma supply rates and higher alkali contents, causing increased viscosity and shorter, steeper rifts [Acosta et al., 2003]. The northern El Hierro rift zones are fanned, as is observed for the northern Wolf rift zones (Figure 4d). Fanning is suggested to arise from insufficient deviatoric stress to trap dike swarms [Acosta et al., 2003], observed only at the distal tips of linear Hawaiian rifts like Puna Ridge [Smith et al., 2002]. Galápagos submarine rift zones appear to reside between the Hawaiian and Canary end-members, having relatively linear axes with scattered examples of fanning, but sharing short lengths with Canary Island rift zones. Short rift zone length for Galápagos rifts is likely a product of lower magma supply rates, as the Galápagos Islands are about $10 \%$ as volcanically active as their
Hawaiian Island counterparts [Allan and Simkin, 2000].

\subsubsection{NW Fernandina Rift Zone}

[22] The NW submarine rift of Fernandina Island is the longest of the western Galápagos submarine rift zones (20 km long), allowing its comparison to Puna Ridge, the 70-km-long submarine continuation of the Kilauea East Rift Zone on the Big Island of Hawai'i [Malahoff and McCoy, 1967; Fornari et al., 1978; Lonsdale, 1989; Smith et al., 2002; Leslie et al., 2004, and references therein]. Fresh lava sampled from the NW rift suggests recent riftzone volcanism [Geist et al., 2006]. The youthful nature of volcanism on the rift is apparent morphologically in the EM300 data from cones located at the shallow end of the rift (Figure 6c), and two large cones with deep craters located approximately halfway down the rift zone have high backscatter reflectivity (Figures $6 \mathrm{~b}$ and $6 \mathrm{~b}^{\prime}$ ). A geophysical manifestation of recent volcanism on the NW rift is a high calculated magnetization value over the shallow SW portion of the rift zone, concentrated at depths less than $2000 \mathrm{~m}$ (Figure 7c). This magnetic signature differs from the three discrete magnetization highs between depths of $1500-$ $2500 \mathrm{~m}$ on Puna Ridge [Smith et al., 2001]. Cross-axial profiles reveal a well-developed, symmetrical rift axis at the shallow end of the NW rift, becoming progressively more irregular at its distal end, reinforcing evidence for recent volcanism focused at the nearshore portion of the NW Fernandina rift zone (Figure 8).

\subsection{Volcanic Cones}

[23] Investigations of subaerial geology [e.g., Banfield et al., 1956; Delaney et al., 1973; Swanson et al., 1974; Chadwick and Howard, 1991; Chadwick and Dieterich, 1995; Rowland, 1996; Naumann and Geist, 2000] have shown that Galápagos eruptions often occur along fissures lined with scorcia and cinder cones, the surface expression of dike rupturing events. Likewise, the EM300 data indicate that the submarine slopes of the Galápagos Islands are dotted with volcanic cones, both lining rift zones and lava terraces [Diefenbach, 2005] and in regions in which volcanic activity is otherwise limited, such as Canal Isabela (Figure 3b).

[24] Steep-sided, pointed cones are found on volcanic flanks and rift zones at water depths generally shallower than $1500 \mathrm{~m}$ (Figures 3a and 3b). These cones are often elongated and slightly curved (examples for southwestern Fernandina 
and northern Santiago shown in Figures 4a and 4c). Clague et al. [2000] accounted for the shallow formation depths for pointed cones as related to a greater expansion of magmatic gas under lower pressure, leading to piling up of fragmental material around the vent. Deep craters, resolved by EM300 bathymetry data, are found solely on rift zones in our study area (Figures 3a, 4e, and 6b), and are interpreted as sites of primary eruption and subsequent lava drain-back [Lonsdale, 1989].

[25] Flat-topped cones are also prevalent on volcanic flanks and rift zones, generally found at water depths greater than $1500 \mathrm{~m}$ in regions with abundant pointed cones at shallower depths, such as southwest Fernandina and the north flank of Santiago Island (Figures 3a, 3b, and $4 a-4 e$ ). This depth dependence of cone morphology has also been observed at Genovesa Ridge [Harpp et al., 2003] and the northeast flank of El Hierro, Canary Islands [Mitchell et al., 2002]. Flat-topped volcanic cones on submarine flanks and rift zones of Hawaiian volcanoes are likely a product of longlived effusive eruption of low volatile content lavas experiencing high confining pressures at moderate to great water depth and gentle slopes [Clague et al., 2000; Zhu et al., 2002]. Central domes and depressions on flat-topped cones are attributed to lava drain-back and rejuvenation of eruptive activity after a hiatus, respectively [Clague et al., 2000]. At the distal end of Puna Ridge, "steps" of flat-topped terraces such as those found in the deep regions of the north flank of Santiago Island (Figure 4c) have been interpreted as flow fronts steepened by mass wasting [Lonsdale, 1989; Smith et al. 2002]. Such semi-circular flat-topped steps have also been found on the northwestern submarine flank of Ni'ihau, Hawai'i [Clague et al., 2000].

\subsection{Vents and Deep Lava Flow Fields}

[26] It has recently been proposed that the deep lava flow fields west and northwest of Fernandina and Ecuador Volcano (Figure 3c) represent initial phases of island-building volcanism that will coalesce into terraces and form a plateau upon which the next island in the Galápagos chain will grow [Geist et al., 2006]. Large lava flow fields (up to $290 \mathrm{~km}^{2}$ ) have been mapped surrounding Roca Redonda and north of Wolf Volcano (Figure 3c). The flow fields ringing Fernandina's NW rift (Figures $3 c$ and $4 c$ ) resemble those in the Hawaiian trough east of Puna Ridge [Holcomb et al., 1988], and those near the distal tip of the NW rift appear to have originated from a field of perched lava ponds resolved in the EM300 bathymetry (Figures 2b, 6a, and $\left.6 a^{\prime}\right)$.

\section{Conclusions}

[27] Analysis of high resolution EM300 bathymetric and MR1 side-scan sonar data has enabled resolution of small-scale features that are key to properly interpreting the volcanic morphology and structure of the seafloor in the western Galápagos. The key volcanic geomorphologic constructs in the western Galápagos Archipelago are rift zones, volcanic cones and deep-water lava flows. We show that volcanism in the western Galápagos occurs both along active rift zones and on volcanic flanks not associated with volcanic rifts. The NW Fernandina rift zone is interpreted to be a site of recent volcanism, suggested by higher calculated magnetization values and abundant constructional volcanic morphologies found in the middle-shallow region of the rift zone's southern flank. Deep craters in submarine volcanic cones in the study area were found solely on rift zones. We observe that the origin of some of the deep lava flows occurs at vents located at the distal tip of rift zones, suggesting a link between these two important submarine volcanic constructional processes. More detailed near-bottom investigations including mapping and feature-specific sampling of the various terrains studied in this paper and Geist et al. [2006] are required to further elucidate the eruptive processes and the spatial/temporal characteristics of the submarine volcanic history of western Galapagos.

\section{Acknowledgments}

[28] We thank Dennis Geist and William Chadwick for constructive reviews. Thanks to Captain Phil Smith and the crew of the R/V Thomas G. Thompson cruises TN188 and TN189, especially marine technicians Rob Hagg and Mike Realander, for their expertise and cooperation in data collection. We thank Roy Carpenter, Russell McDuff, and Rick Keil at UW for organizing the unique opportunity for undergraduate oceanographic research around the Galápagos Archipelago on TN189, and the State of Washington and generous donors for funding undergraduate research time. Thanks to the Galápagos National Park for providing technical and logistical support during the cruise, INOCAR for providing scientific assistance, and DIGEIM for granting all the necessary permits for TN189. We thank Maurice Tivey for providing MatLab ${ }^{\circledR}$ scripts for magnetic inversions, helpful discussions, and technical support. Thanks to Roger Goldsmith and Adam Soule for technical support. We thank the teaching staff with M.L.H. of the 2005 2006 UW Oceanography senior project class: Roy Carpenter, 
Seelye Martin, Gabrielle Rocap, and Llyd Wells. We thank our UW Oceanography classmates for their support. Thanks to Mark Kurz and Joshua Curtice for DRIFT4 dredge samples and assistance, and Clare Williams for assistance with sample preparation and magnetic measurements. We thank Mimi D'Iorio, Miles Logsdon, and Jill Coyle of the UW Spatial Analysis Laboratory for technical support and guidance. We thank Deborah Smith, Hans Schouten, Robin Holcomb, John Delaney, and David Clague for helpful discussions. J.B.G. thanks the UW School of Oceanography for the Backus Scholarship and the Woods Hole Oceanographic Institution and generous donors for their support of the WHOI Summer Student Fellow Program. Data collected on TN188 was funded by NSF grant OCE0326148 and NOAA grant NA04OAR460009 to S.M.W. Support for data collected on previous multibeam and MR1 cruises was provided by NSF grants OCE9811504 and OCE0002461 (D.J.F.).

\section{References}

Acosta, J., E. Uchupi, D. Smith, A. Muñoz, P. Herranz, C. Palomo, P. Llanes, M. Ballesteros, and ZEE Working Group (2003), Comparison of volcanic rifts on La Palma and El Hierro, Canary Islands and the Island of Hawaii, Mar. Geophys. Res., 24, 59-90.

Allan, J. F., and T. Simkin (2000), Fernandina Volcano's evolved, well-mixed basalts: Mineralogical and petrological constraints on the nature of the Galapagos plume, J. Geophys. Res., 105(B3), 6017-6042.

Ballard, R. D., R. T. Holcomb, and T. H. van Andel (1979), The Galapagos rift at $86^{\circ} \mathrm{W}: 3$. Sheetflows, collapse deeps and lava lake of the rift valley, J. Geophys. Res., 84, 5407-5422.

Banfield, A. F., C. H. Behre, Jr., and D. St. Clair (1956), Geology of Isabela (Albemarle) Island, Archipelago de Colon (Galápagos), Bull. Geol. Soc. Am., 67, 215-234.

Cando, M., P. Arreaga, T. Toulkeridis, and G. De La Torre (2006), Evidences for potential future sector collapse at Volcano Roca Redonda, northern Galápagos-Tectonics, simulation and consequences, paper presented at 4th Meeting, Cities on Volcanoes, Int. Assoc. of Volcanol. and Chem. of the Earth's Inter., Quito, Ecuador, 23 -27 Jan.

Chadwick, W. W.Jr., and J. H. Dieterich (1995), Mechanical modeling of circumferential and radial dike intrusions on Galápagos volcanoes, J. Volcanol. Geotherm. Res., 66, 37-52.

Chadwick, W. W.Jr., and K. A. Howard (1991), The pattern of circumferential and radial eruptive fissures on the volcanoes of Fernandina and Isabela islands, Galápagos, Bull. Volcanol., 53, 259-275.

Christie, D. M., R. A. Duncan, A. R. McBirney, M. A. Richards, W. M. White, K. S. Harpp, and C. G. Fox (1992), Drowned islands downstream from the Galápagos hotspot imply extended speciation times, Nature, 355, $246-248$.

Clague, D. A., J. G. Moore, and J. R. Reynolds (2000), Formation of submarine flat-topped volcanic cones in Hawai'i, Bull. Volcanol., 62, 214-233.

Corliss, J. B., et al. (1979), Submarine thermal springs on the Galápagos Rift, Science, 203, 1073-1083.

Darwin, C. (1860), The Voyage of the Beagle, 524 pp., Doubleday, New York.

Darwin, C. (1896), Geological Observations on the Volcanic Islands and Parts of South America Visited During the Voyage of the H. M. S. Beagle, , 648 pp., D. Appleton, New York.
Delaney, J. R., W. E. Colony, T. M. Gerlach, and B. E. Nordlie (1973), Geology of the Volcan Chico Area on Sierra Negra Volcano, Galápagos Islands, Geol. Soc. Am. Bull., 84, 24552470.

Diefenbach, B. (2005), Volcanic construction of the Galápagos Platform: Evidence from the morphology and geochemistry of large submarine terraces, M. S. thesis, 91 pp., Univ. of Idaho at Moscow, Moscow, June.

Fornari, D. J., A. Malahoff, and B. C. Heezen (1978), Volcanic structure of the crest of the Puna Ridge, Hawaii: Geophysical implications of submarine volcanic terrain, Geol. Soc. Am. Bull., 89, 605-616.

Fornari, D. J., M. D. Kurz, D. J. Geist, P. D. Johnson, G. Peckman, and D. Scheirer (2001), New perspectives on the structure and morphology of the submarine flanks of Galápagos volcanoes-Fernandina and Isabela, Eos Trans. $A G U, 82(47)$, Fall Meet. Suppl., Abstract T41D-06.

Geist, D., W. M. White, F. Albarede, K. Harpp, R. Reynolds, J. Blichert-Toft, and M. D. Kurz (2002), Volcanic evolution in the Galápagos: The dissected shield of Volcan Ecuador, Geochem. Geophys. Geosyst., 3(10), 1061, doi:10.1029/ 2002GC000355.

Geist, D. J., T. R. Naumann, J. J. Standish, M. D. Kurz, K. S. Harpp, W. M. White, and D. J. Fornari (2005), Wolf Volcano, Galápagos Archipelago: Melting and magmatic evolution at the margins of a mantle plume, J. Petrol., 46, 2197-2224.

Geist, D. J., D. J. Fornari, M. D. Kurz, K. S. Harpp, S. Adam Soule, M. R. Perfit, and A. M. Koleszar (2006), Submarine Fernandina: Magmatism at the leading edge of the Galápagos hot spot, Geochem. Geophys. Geosyst., 7, Q12007, doi:10.1029/2006GC001290.

Graham, D. W., D. M. Christie, K. S. Harpp, and J. E. Lupton (1993), Mantle plume helium in submarine basalts from the Galápagos platform, Science, 262, 2023-2026.

Gripp, A. E., and R. G. Gordon (2002), Young tracks of hotspots and current plate velocities, Geophys. J. Int., 150, 321-361.

Harpp, K. S., D. J. Fornari, D. J. Geist, and M. D. Kurz (2003), Genovesa Submarine Ridge: A manifestation of plume-ridge interaction in the northern Galápagos Islands, Geochem. Geophys. Geosyst., 4(9), 8511, doi:10.1029/2003GC000531.

Holcomb, R. T., J. G. Moore, P. W. Lipman, and R. H. Belderson (1988), Voluminous submarine lava flows from Hawaiian volcanoes, Geology, 16, 400-404.

Kurz, M. D., and D. J. Geist (1999), Dynamics of the Galapagos hotspot from helium isotope geochemistry, Geochim. Cosmochim. Acta, 63, 4139-4156.

Kurz, M. D., D. J. Fornari, J. M. Curtice, M. Perfit, D. Scheirer, and D. J. Geist (2001), The leading edge of the Galápagos hotspot: New submarine evidence from Fernandina Volcano, Eos Trans. AGU, 82(47), Fall Meet. Suppl., Abstract T42B-938.

Leslie, S. C., G. F. Moore, and J. K. Morgan (2004), Internal structure of Puna Ridge: Evolution of the submarine East Rift Zone of Kilauea Volcano, Hawai'i, J. Volcanol. Geotherm. Res., 129, 237-259.

Lonsdale, P. (1989), A geomorphological reconnaissance of the submarine part of the East Rift Zone of Kilauea Volcano, Hawaii, Bull. Volcanol., 51, 123-144.

Malahoff, A., and F. McCoy (1967), The geologic structure of Puna submarine ridge, Hawaii, J. Geophys. Res., 72, $541-$ 548.

Mitchell, N. C. (2001), Transition from circular to stellate forms of submarine volcanoes, J. Geophys. Res., 106(B2), 1987-2004. 
Mitchell, N. C. (2003), Susceptibility of mid-ocean ridge volcanic islands and seamounts to large-scale landsliding, J. Geophys. Res., 108(B8), 2397, doi:10.1029/ 2002JB001997.

Mitchell, N. C., D. G. Masson, A. B. Watts, M. J. R. Gee, and R. Urgeles (2002), The morphology of the submarine flanks of volcanic ocean islands: A comparative study of the Canary and Hawaiian hotspot islands, J. Volcanol. Geotherm. Res., 115, 83-107.

Naumann, T., and D. Geist (2000), Physical volcanology and structural development of Cerro Azul Volcano, Isabela Island, Galápagos: Implications for the development of Galápagos-type shield volcanoes, Bull. Volcanol., 61, 497-514.

Parker, R. L. (1973), The rapid calculation of potential anomalies, Geophys. J. R. Astron. Soc., 31, 441-455.

Parker, R. L., and S. P. Huestis (1974), The inversion of magnetic anomalies in the presence of topography, J. Geophys. Res., 79, 1587-1594.

Rowland, S. K. (1996), Slopes, lava flow volumes, and vent distributions on Volcán Fernandina, Galápagos Islands, J. Geophys. Res., 101(B12), 27,657-27,672.

Rowland, S. K., D. C. Munro, and V. Perez-Oviedo (1994), Volcán Ecuador, Galapágos Islands: Erosion as a possible mechanism for the generation of steep-sided basaltic volcanoes, Bull. Volcanol., 56, 271-283.

Simkin, T. (1984), Geology of the Galápagos Islands, in Galápagos (Key Environments), edited by R. Perry, pp. 15-41, Elsevier, New York.
Sinton, C. S., D. M. Christie, and R. A. Duncan (1996), Geochronology of Galapágos seamounts, J. Geophys. Res., 101(B6), 13,689-13,700.

Smith, D. K., M. A. Tivey, P. M. Gregg, and L. S. L. Kong (2001), Magnetic anomalies at the Puna Ridge, a submarine extension of Kilauea Volcano: Implications for lava deposition, J. Geophys. Res., 106(B8), 16,047-16,060.

Smith, D. K., L. S. L. Kong, K. T. M. Johnson, and J. R. Reynolds (2002), Volcanic morphology of the submarine Puna Ridge, Kilauea Volcano, in Hawaiian Volcanoes: Deep Underwater Perspectives, Geophys. Monogr. Ser., vol. 128, edited by E. Takahashi et al., pp. 125-142, AGU, Washington, D. C.

Standish, J., D. Geist, K. Harpp, and M. D. Kurz (1998), The emergence of a Galápagos shield volcano, Roca Redonda, Contrib. Mineral. Petrol., 133, 136-148.

Swanson, F. J., H. W. Baitis, J. Lexa, and J. Dymond (1974), Geology of Santiago, Rábida, and Pinzón Islands, Galápagos, Geol. Soc. Am. Bull., 85, 1803-1810.

Vogt, P. R., and N. C. Smoot (1984), The Geisha Guyots: Multibeam bathymetry and morphometric interpretation, J. Geophys. Res., 89(B13), 11,085-11,107.

Wilson, D. S., and R. N. Hey (1995), History of rift propagation and magnetization intensity for the Cocos Nazca Spreading Center, J. Geophys. Res., 100(B6), 10,041-10,056.

Zhu, W., D. K. Smith, and L. G. J. Montési (2002), Effects of regional slope on viscous flows: A preliminary study of lava terrace emplacement at submarine volcanic rift zones, J. Volcanol. Geotherm. Res., 119, 145-159. 